\title{
OCCURRENCE OF QUINOLONE RESISTANCE GENES AMONG SALMONELLA SPECIES ISOLATED FROM CHICKENS
}

Etab M. Abo-Remela ${ }^{1}$ Wafaa M. Gad ${ }^{2}$, Salwa M. Helmy ${ }^{1}$, Wafaa M. Hassan $^{3}$

\author{
${ }^{1}$ Bacteriology, Mycology and Immunology Department, Faculty \\ of Veterinary Medicine, Kafrelsheikh University. \\ ${ }^{2}$ Animal Health Research Institute, Dakahlia branch. \\ ${ }^{3}$ Animal Health Research Institute, Dokki Lab., Giza.
}

\begin{abstract}
Resistance to antimicrobial agents within nontyphoidal Salmonella serotypes is considered a serious problem worldwide so this study was aimed to investigate the wide spread Plasmid-mediated quinolone resistance between different Salmonellae isolated from chickens. The antimicrobial susceptibility was applied on all isolates then PCR was applied for most resistant isolates to quinolones to detect the Plasmidmediated quinolone resistance genes (qnrA, qnrB, qnrS). Forty one Salmonella isolates (9.1\%) were obtained from 450 samples. All isolates exhibit resistance against all antimicrobial agents except amikacin in which give no resistance. All isolates showed resistance with 100\% against nalidixic acid and flumequin but 4 isolates showed the lowest resistance (9.7\%) to levofloxacin. Five isolates were sensitive to amoxicillin giving the lowest percentage (12.1\%). Twenty two Salmonella isolates from a total of 41 isolates were examined by PCR for Plasmid-mediated quinolone resistance genes (qnrA, qnrB, and qnrS). while 19 Salmonella isolates not examined as they were less resistant to quinolones. Five isolates (5/22) (22.7\%) were positive for qnrA, 2 isolates (2/22) (9\%) were positive for qnrB and 4 isolates (4/22) (18\%) were positive for qnrS.
\end{abstract}


Keywords: Salmonella,Plasmid-mediated resistance genes, chickens, Egypt.

\section{INTRODUCTION}

Avian salmonellosis is a problem of economic concern to all phases of poultry industry from production to marketing. As a result of extensive use of antibiotics in human and veterinary medicine, serious increase in the spreading of multiple antibiotic resistant Salmonella has occurred (Cruchaga et al., 2001). Antimicrobial resistance is a global public health problem. Although all countries are affected, the extent of the problem in the developing nations is unknown (Ang et al., 2004). First, qnrA1 from a clinical strain of Klebsiella pneumoniae isolated in Alabama was described. This strain carried plasmid pMG252, which contained the gene encoding quinolone resistance, later named qnrA1 (Martinez et al., 1998). Another qnr gene from a Shigella flexneri isolated during an outbreak of food poisoning in Japan. This strain contained a plasmid, designated pAH0376, containing a gene with high similarity to $q n r$, which was designated $q n r \mathrm{~S}$. The $q n r \mathrm{~S}$ protein was also a 218 -amino acid protein with $59 \%$ similarity to qnrA that conferred low level resistance to fluoroquinolones (Hata et al., 2005). In 2006, Jacoby and colleagues described a third gene encoding quinolone resistance, $q n r \mathrm{~B}$. This gene was first found in a Klebsiella pneumoniae isolate from India and encoded a 214- amino-acid protein of the pentapeptide repeat family, which had $41 \%$ amino acid identity with qnrA and $39 \%$ amino acid identity with qnrS (Jacoby et al., 2006). To date, a total of 6 qnrA, $4 q n r \mathrm{~S}$, and $20 q n r \mathrm{~B}$ variants have been described in the literature and are listed in the database maintained at the website 
http://www.lahey.org/qnrStudies (Jacoby et al., 2008). Later, other transferable resistance genes were found to cause reduced susceptibility to quinolones. The aminoglycoside acetyltransferase variant aac(6_)Ib-cr is able to modify ciprofloxacin and norfloxacin. Moreover, in 2007, in Japan, but also in Belgium, another gene, qepA, was discovered to encode a putative specific efflux pump, which is able to reduce susceptibility to hydrophilic quinolones. (Cavaco et al., 2008). Furthermore, a second variant, named qepA2, from France was recently described (Cattoir et al., 2008). Recently, Wang and colleagues described another $q n r$ gene, $q n r \mathrm{C}$, which was found in Proteus mirabilis; however, its sequence is not yet publicly available, but it was found that qnrC encodes a 221-amino-acid protein with different amino acid identities from $q n r \mathrm{D}$, which indicates that the gene is different from qnrD (Wang et al., 2008). qnrD, which has been found to cause reduced susceptibility to fluoroquinolones in isolates of Salmonella enterica serovar Bovismorbificans and Kentucky strains isolated from humans in the Henan province of China. The complete plasmid was sequenced, and the novel qnrD gene was cloned along with both the qnrA1 and qnrS1 genes, which were cloned for comparisons of the susceptibility patterns in vitro. The novel $q n r \mathrm{D}$ gene shares similarities with the previously described $q n r$ genes and encodes a putative pentapeptide repeat protein that is able to confer reduced susceptibility to fluoroquinolones. A phylogenetic analysis shows that it clusters separately from the known $q n r$ genes and variants. (Cavaco et al., 2008) Here, we investigated the 
presence of Plasmid-mediated resistance genes of Salmonella isolated from chickens in Egypt.

\section{MATERIAL AND METHODS}

\subsection{Sampling and isolation of Salmonella:}

A total of 450 samples from apparently healthy and diseased chickens were collected and transferred immediately in ice box to bacteriology laboratory under aseptic condition. The samples were first pre-enriched in buffered peptone water at $37{ }^{\circ} \mathrm{C}$ for $18-24 \mathrm{~h}$. Then, a 0.1 $\mathrm{ml}$ of pre-enriched broth was transferred to $10 \mathrm{ml}$ of Rappaport Vassiliadis broth and incubated at $37{ }^{\circ} \mathrm{C}$ for $18 \mathrm{~h}$, subcultured on MacConky and xylose lysine deoxycholate (XLD) agars, and incubated at $37{ }^{\circ} \mathrm{C}$ for $24-48 \mathrm{~h}$. Suspected Salmonella spp., based on colony morphology on the selective media, were identified biochemically (according to ISO 6579 (2002)_method and also confirmed by API 20E system (BioMérieux, Marcy-L’Etoile, France).

\subsection{Serological typing of Salmonella:}

The isolates that were identified biochemically as Salmonella were subjected to serological identification according to Kauffman-White Scheme (Kauffman, 1974) for determination of somatic (O) and flagellar (H) antigen.

\subsection{Antimicrobial susceptibility testing:}

The antimicrobial susceptibility testing was done according to Finegold and Martin (1982) using the agar disc diffusion method on 
Mueller Hinton agar (Oxoid) plates. The used antimicrobial agents were Nalidixic acid $(30 \mu \mathrm{g})$, Flumequine $(30 \mu \mathrm{g})$, Ciprofloxacin $(5 \mu \mathrm{g})$, Enrofloxacin $(5 \mu \mathrm{g})$, Norfloxacin $(10 \mu \mathrm{g})$, Levofloxacin $(5 \mu \mathrm{g})$, Amoxicillin $(10 \mu \mathrm{g})$, Ampicillin - sulbactam $(20 \mu \mathrm{g})$, Cefotaxime $(30 \mu \mathrm{g})$, Ceftriaxone $(30 \mu \mathrm{g})$, Ceftazidime $(30 \mu \mathrm{g})$, Neomycin $(30 \mu \mathrm{g})$, Amikacin

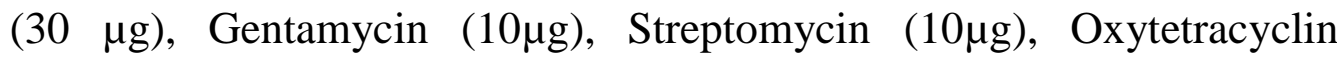
$(30 \mu \mathrm{g})$ and Sulfamrthoxazole- Trimethoprim $(25 \mu \mathrm{g})$. The zones of inhibition that formed were measured to assess resistance or susceptibility according to the interpretation criteria established by (CLSI) standard (2005).

\subsection{Detection of resistance genes in isolated Salmonellae using PCR}

\subsubsection{Bacterial DNA preparation for PCR}

An overnight bacterial culture $(200 \mu \mathrm{l})$ was mixed with $800 \mu \mathrm{l}$ of distilled water and boiled for $10 \mathrm{~min}$. The resulting solution was centrifuged and the supernatant was used as the DNA template. Amplification reactions were carried out with $10 \mu \mathrm{l}$ of boiled bacterial suspensions, $250 \mu \mathrm{m}$ deoxynucleoside triphosphate, $2.5 \mu \mathrm{m} \mathrm{MgCl} 2,50$ pmol of primers and 1U of AmpliTaq Gold DNA Polymerase (Applied Biosystems, Roche, NJ, USA). Distilled water was added to bring the final volume to $50 \mu \mathrm{l}$. After PCR reactions, the reaction products were subjected to electrophoresis in a $1.0 \%$ agarose gel, stained with ethidium bromide and visualized under UV light.

\subsubsection{Screening for plasmid mediated quinolone resistance genes}


The Salmonella isolates were tested for plasmid-mediated quinolone resistance genes $q n r \mathrm{~A}, q n r \mathrm{~B}$, and $q n r \mathrm{~S}$ with primers described in Table (1)

\section{RESULTS AND DISCUSSION}

\subsection{Isolation and identification of Salmonella}

Salmonella spp. are important food-borne pathogens that are demonstrating increasing antimicrobial resistance rates in isolates obtained from food animals and humans. Increased antimicrobial resistance has been attributed to various animal and human sources via clonal dissemination and direct selection pressure through the use of antimicrobial agents (Angulo and Griffin, 2000). In this study 450 samples were examined for presence of Salmonella. Forty one (9.1\%) out of 450 birds were found positive for Salmonella isolation. The results in this study agreed with El-Morsi (1998) who isolated Salmonella species from liver samples of chicks with an incidence of 12\%, Rehan (2004) who isolated Salmonella species from broiler chickens with an incidence of $12 \%$ and Ammar et al., (2010) who identified the most common Salmonella serovars in broilers and laying breeding reproducers in Eastern Algeria and isolated S. Typhimurium with incidence of (12\%) but the results in this study nearly in coordinated with Schluter et al., (1994) who isolated Salmonella from laying chicken flocks $13.3 \%$ and Dahal (2007) who examined 400 chicken samples to detect the prevalence of Salmonella in them which was $13 \%$. On the other hand the results of this study differ from Osman (1992) who collected 150 random samples from different broiler farms, and isolated 45 Salmonella 
strains with an incidence of 30\%, Schluter et al., (1994) who isolated Salmonella from chicken broiler flocks with an incidence of $6.2 \%$, Mohamed et al., (1999) who isolated Salmonella from 200 faecal samples from living chickens at Kafr El- Sheikh Governorate, the incidence of isolation was $2.5 \%$, Jafari et al., (2007) who isolated Salmonella from 422 apparently healthy chickens in Iran, five samples $5.8 \%$ out of 85 pooled samples were positive for Salmonella and Islam et al., (2006) who recorded 33 Salmonella isolates from layer chickens in Dhaka and Gazipur regions of Bangladesh.

\subsection{Salmonella serotyping}

Salmonella isolates were serotyped using poly and monovalent "O" and " $\mathrm{H}$ " antisera and the results of this study revealed that 18 strains were isolated(8) (19.5\%) S. Typhimurium, (1) (2.4\%) S. Apeyeme, (4) (9.7\%) S. Kentucky, (1) (2.4\%) S. Daula, (6) (14.6\%) S. Newport, (3) (7.3\%) S. Tamale, (3) (7.3\%) S. Molade, (1) (2.4\%) S. Colindale, (1) (2.4\%) S. Lexington, (2) (4.8\%) S. Bargny, (2) (4.8\%) S. Enteritidis, (1) (2.4\%) S. Papuana, and (1) (2.4\%) S. Labadi, (2) (4.8\%) S. Santiago (2) (4.8\%) S. Magherafelt, (1) (2.4\%) S. Rechovot (1) (2.4\%) S. Takoradi, and (1) (2.4\%) S. Angers. The results in this study reported that $S$. Typhimurium participated with the higher percentage from the isolated serotypes $(19.5 \%)$ by 8 isolates while $S$. Apeyeme, $S$. Daula, $S$. Colindale, $S$. Lexington, $S$. Papuana, S. Labadi, S. Rechovot S.Takoradi, and $S$. Angers participated with the lower percentage $(2.4 \%)$ by one isolate for each of them. These results agreed with Verma and Gupta (1995) who isolated $S$. Typhimurium with a percentage of (18.10\%) 
While these results differ from Edel et al., (1991) who recorded $\mathrm{S}$. Entertidis with an incidence of $1.4 \%$ for laying flocks and $1.1 \%$ for broiler breeder flocks in Netherland in 1990, Osman (1992) who isolated 45 Salmonellae from different broiler farms with an incidence of $30 \%$ and the serological typing revealed 21 (46.7\%) S. Pullorum, 9(20\%) S.Gallinarum, 7 (15.6\%) S. Typhimurium and 8 (17.8\%) S. Entertidis, Ibrahim (1995) who isolated 55 strains of Salmonella species, 22 were from chicks, 18 from broilers and 15 from layers. The isolated serovars were $S$. Montevideo, $S$. Typhimurium, $S$. Entertidis, $S$. Lexington, $S$. Infantis, S. Reading, S. Cerro, S. Hadar and S. Tennesee, Toh et al., (1996) who reported 608 isolates of Salmonella at the Central Veterinary Laboratory Singapore. A total of 560 of the isolates belonged to 72 serotypes and 14 serogroup while other 48 were untypable. The commonest serotypes isolated were $S$. Typhimurium (23.8\%), S. Weltevereden (10\%), S. Bockly (5.1\%), S. Brraenderup (3.9\%) and $S$. Entertidis (3.3\%), EL-Zeedy et al., (2007) who isolated 17 isolates of $S$. Typhimurium and one isolate of S. Kentucky, Bonyadian et al., (2007) who determined the prevalence of Salmonellae contamination of chicken carcasses in slaughterhouses in central Iran (Yazd province). Serological tests showed that $S$. Typhimurium was the main contaminant of the samples (52.2\%). solated serotypes were $S$. Newport (15.6\%), $S$. Enteritidis (12.2\%), S. Havana (8.9\%), S. Dublin (5.6\%) and $S$. Paratyphi-B (5.6\%).

\subsection{Antimicrobial susceptibility testing}


All isolates exhibit resistance against all antimicrobial agents except amikacin which give no resistance and these results agreed with Snow et al., (2011) who reported that all Salmonella isolates from commercial layer flocks in UK were sensitive to amikacin with (100\%). Forty one chicken isolates showed resistance with $100 \%$ against nalidixic acid and flumequin but four isolates showed the lowest resistance $(9.7 \%)$ to levofloxacin. Thirty seven isolates were sensitive to levofloxacin with $(90.2 \%)$ while 5 isolates were sensitive to amoxicillin giving the lowest percentage (12.1\%) Table (2). The obtained results differ from Boris $\boldsymbol{e t}$ al., (2012) who reported that all Salmonella isolates were sensitive to chloramphenicol and streptomycin (100\%) while 92 isolates $(58 \%)$ were sensitive to nalidixic acid and of $66(41.7 \%)$ isolates were sensitive to all antibiotics. Contrary to these results Cardoso et al., (2006) who reported that Salmonella showed sensitivity to doxycycline hydrochloride with 100\%. However Khan et al., (2010) stated that all Salmonella isolates exhibit (100\%) resistant to cephalexin and rifampicin while about $90 \%$ and $88 \%$ of the isolates were resistant to ampicillin and tetracycline. The results in this study differ from Zdragas et al., (2012) who reported (5\%) resistance to streptomycin (highest resistance rates) and (2\%) to tetracycline and nalidixic acid (lowest rate), Munawwar et al., (2010) who reported (100\%) resistance to cephalexin and rifampicin in Salmonella isolated from chicken meats in Dubai, while $87.88 \%$ of these Salmonellae were sensitive to ciprofloxacin and amikacin.

\subsection{Polymerase Chain Reaction technique for different resistance genes in the examined isolates}

Fluoroquinolones are broad-spectrum antimicrobial agents widely used in clinical medicine. Resistance to this class of antibacterials is Kafrelsheikh Vet. Med. J. Vol. 13 No. 2 (2015) 
usually caused by mutations in the chromosomal genes that code for DNA gyrase and/or DNA topoisomerase IV, the target enzymes, and/or mutations resulting from alterations in drug accumulation (Ruiz, 2003). Quinolone resistance encoded by the plasmid-mediated quinolone resistance gene, qnr, was first discovered in a clinical strain of Klebsiella pneumoniae isolated in 1994 (Martinez et al., 1998). The qnr gene confers nalidixic acid and low-level fluoroquinolone (e.g., ciprofloxacin) resistance (Robicsek et al., 2006a). Plasmid-mediated quinolone resistance is of concern because the resistance determinants are potentially disseminated among bacteria because of plasmid mobility. There are at least three main types of qnr gene, qnrA, qnrB and qnrS (Robicsek et al., 2006a). In this study twenty two Salmonella isolates out of 41 isolates that showed more resistance to quinolones in antimicrobial susceptibility tests were examined by PCR for $q n r \mathrm{~A}, q n r \mathrm{~B}$ and $q n r \mathrm{~S}$ (Plasmid-mediated quinolone resistance genes) while 19 Salmonella isolates not examined by PCR for these genes as they were less resistant to quinolone in antimicrobial susceptibility tests. Five isolates $(5 / 22)$ (22.7\%) were positive for qnrA gene from the 22 examined isolates giving amplification of $516 \mathrm{bp}$ fragments. Also the positive control showed $516 \mathrm{bp}$ fragments whereas no amplification could be observed with the negative control (figures 1) Table (3). Two isolates (2/22) (9\%) were positive for $q n r \mathrm{~B}$ gene from the 22 examined isolates giving amplification of $469 \mathrm{bp}$ fragments. Also the positive control showed 469 bp fragments whereas no amplification could be observed with the negative control (figures 2) Table (3). Four isolates (4/22) (18\%) were 
positive for qnrS gene from the 22 examined isolates giving amplification of $417 \mathrm{bp}$ fragments. Also the positive control showed 417 bp fragments whereas no amplification could be observed with the negative control (figures 3) Table (3). While (Ahmed et al., 2009b) reported that $q n r S$ and $q n r \mathrm{~B}$ were identified in two isolates of S. enterica serovar Enteritidis and one isolate of S.enterica serovar Typhimurium respectively. qnrS was identified previously in S. enterica serovar Typhimurium isolated from animals in Japan (Ahmed et al., 2009a) and S. enterica serovar Infantis of avian origin in Germany (Kehrenberg et al., 2006). Also, qnrB was previously identified in many S. enterica serovars, such as Mbandaka and Berta isolated from patients in the United States (Gay et al., 2006), and Stanley, Typhimurium, Virchow and Virginia from patients in the United Kingdom (Hopkins et al., 2007). No Plasmid-mediated quinolone resistance gene was identified in 224 Salmonella spp. isolates. (Xiang et al., 2011).

Table (1): Primers used for gene amplification

\begin{tabular}{||c||c||c||c||}
\hline Primers & Nucleotide Sequence & $\begin{array}{c}\text { Annealing } \\
\text { temperature }\end{array}$ & References \\
\hline \hline Plasmid-mediated quinolone resistance & & \\
\hline \hline qnrA & F(5'- ATTTCTCACGCCAGGATTTG -3') & $53^{\circ} \mathrm{C}$ & Robicsek et al., 2006b \\
\hline qnrB & R (5'-GATCGGCAAAGGTTAGGTCA -3') & & Robicsek et al., \\
\hline
\end{tabular}

$\overline{\text { Kafrelsheikh Vet. Med. J. Vol. } 13 \text { No. } 2 \text { (2015) }}$ 
Occurrence Of Quinolone Resistance Genes Among ...

Etab M. Abo-Remela et., al.

\begin{tabular}{|c|c|c|c|}
\hline & R(5'- ACGATGCCTGGTAGTTGTCC $\left.\quad-3^{\prime}\right)$ & & $2006 b$ \\
\hline qnrS & $\begin{array}{l}\text { F(5'- ACGACATTCGTCAACTGCAA -3') } \\
\text { R(5'- TAAATTGGCACCCTGTAGGC -3') }\end{array}$ & $53^{\circ} \mathrm{C}$ & $\begin{array}{c}\text { Robicsek et al., } \\
2006 b\end{array}$ \\
\hline
\end{tabular}

Table (2): Numbers and percentages of Salmonella isolates exhibiting resistance to various antimicrobial agents.

\begin{tabular}{|c|c|c|c|c|}
\hline \multirow{2}{*}{ Antimicrobial Agent } & \multicolumn{2}{|c|}{ Resistant Isolates } & \multicolumn{2}{|c|}{ Senstive Isolates } \\
\hline & No & $\% *$ & No & $\% *$ \\
\hline Nalidixic acid & 41 & 100 & $\overline{0} 0$ & $\overline{0} 0$ \\
\hline Flumequin & 41 & 100 & 0 & 0 \\
\hline Ciprofloxacin & 13 & 31.7 & 28 & 68.2 \\
\hline Enerofloxacin & 20 & 48.7 & 21 & 51.2 \\
\hline Norfloxacin & 8 & 19.5 & 33 & 80.4 \\
\hline Levofloxacin & 4 & 9.7 & 37 & 90.2 \\
\hline Amoxicillin & 36 & 87.8 & 5 & 12.1 \\
\hline Ampicilliln+ sulb & 33 & 80.4 & 8 & 19.5 \\
\hline Cefotaxime & 7 & 17 & 34 & 82.9 \\
\hline Ceftriaxone & 9 & 21.9 & 32 & 78 \\
\hline Ceftazidime & 9 & 21.9 & 32 & 78 \\
\hline Neomycin & 17 & 41.4 & 24 & 58.5 \\
\hline Amikacin & 0 & 0 & 41 & 100 \\
\hline Gentamycin & 12 & 29.2 & 29 & 70.7 \\
\hline Streptomycin & 23 & 56 & 18 & 43.9 \\
\hline Oxytetracyclin & 32 & 78 & 9 & 21.9 \\
\hline Sulfa+trimethoprim & 28 & 68.2 & 13 & 31.7 \\
\hline
\end{tabular}

Table (2): Results of Polymerase Chain Reaction technique for Plasmidmediated resistance genes from the examined isolates.

\begin{tabular}{|c|c|c|c|c|}
\hline Code No & $q n r \mathrm{~A}$ & $q n r \mathrm{~B}$ & $q n r \mathrm{~S}$ & Serotype \\
\hline 9 & - & - & - & S. Daula \\
\hline 10 & + & - & - & S. Newport \\
\hline 11 & - & - & + & S. Tamale \\
\hline 12 & + & - & - & S. Molade \\
\hline 13 & - & - & - & S.Typhmurium \\
\hline 14 & + & - & - & $S$. Newport \\
\hline 17 & - & - & - & S. Lexington \\
\hline 18 & - & + & - & $S$. Bargny \\
\hline 19 & + & - & + & S. Rechovot \\
\hline 21 & - & - & - & $S$. Enteritidis \\
\hline 22 & - & - & + & $S$. Magherafelt \\
\hline 23 & - & - & - & S.Typhmurium \\
\hline
\end{tabular}

Kafrelsheikh Vet. Med. J. Vol. 13 No. 2 (2015) 
Etab M. Abo-Remela et., al.

\begin{tabular}{|c|c|c|c|c|}
\hline 25 & - & - & - & $S$. Labadi \\
\hline 26 & - & - & + & S. Apeyeme \\
\hline 27 & - & + & - & S. Tamale \\
\hline 28 & - & - & - & $S$.Enteritidis \\
\hline 32 & - & - & - & S. Molade \\
\hline 33 & - & - & - & S. Kentucky \\
\hline 34 & - & - & - & S. Newport \\
\hline 35 & - & - & - & S. Kentucky \\
\hline 36 & + & - & - & S. Newport \\
\hline 41 & - & - & - & S. Bargny \\
\hline
\end{tabular}

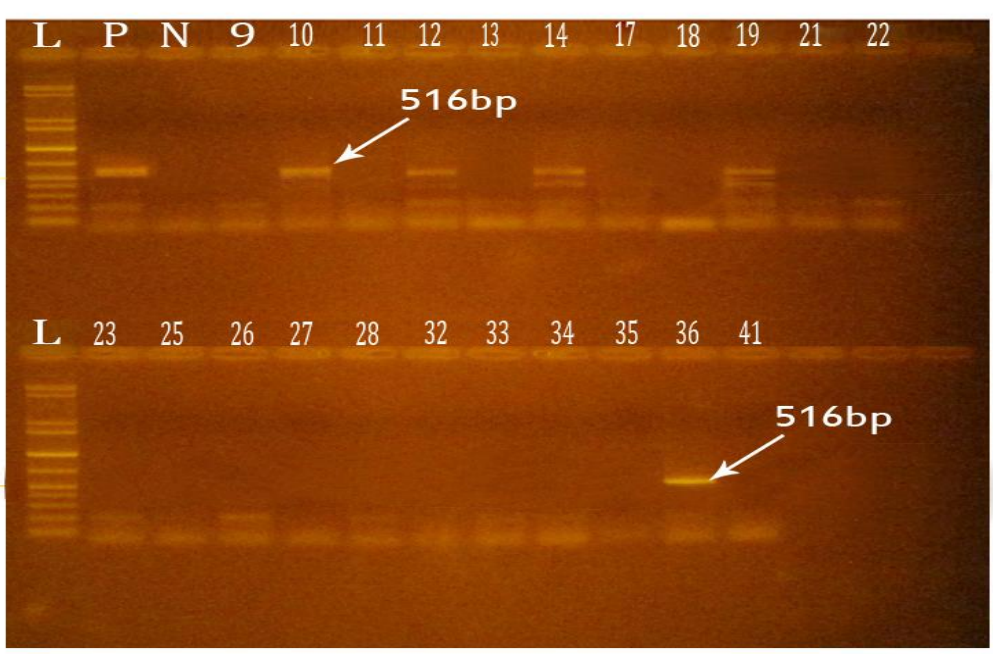

Fig. (1): Agarose gel electrophoresis showing specific PCR of Salmonella isolates using primer set for $q n r \mathrm{~A}$ gene (516 bp) - $\mathrm{L}=$ ladder\& lane $\mathrm{P}=$ positive control\& lane $\mathrm{N}=$ negative control and lanes $(10,12,14,19,36)$ were positive for this gene. 


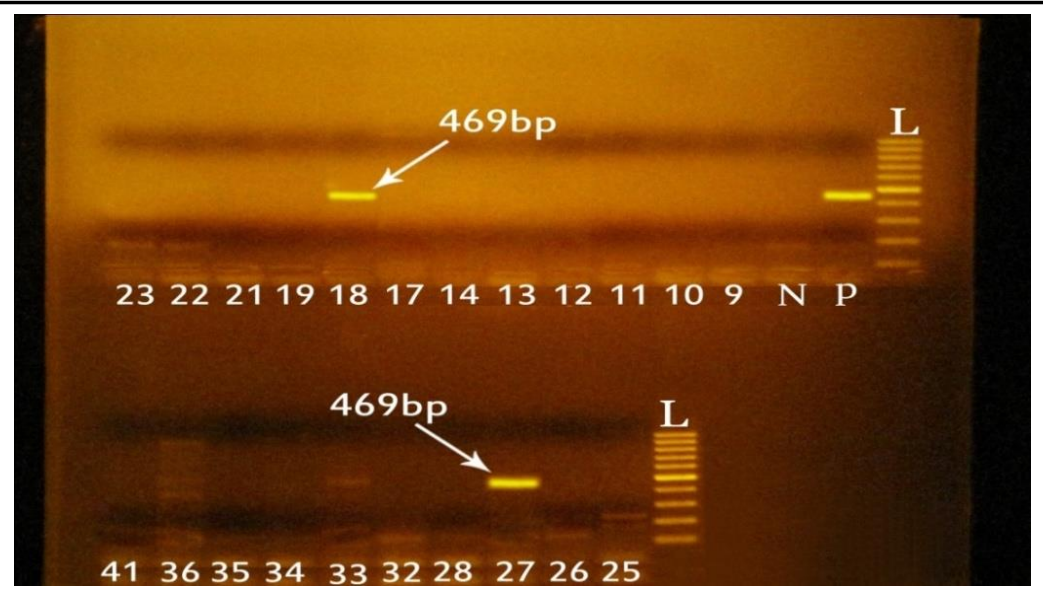

Fig. (2): Agarose gel electrophoresis showing specific PCR of Salmonella isolates using primer set for $q n r \mathrm{~B}$ gene (469 bp) - $\mathrm{L}=$ ladder\& lane $(1)=$ positive control\& lane $(2)=$ negative control and lanes $(18$ and 27) were positive for this gene.

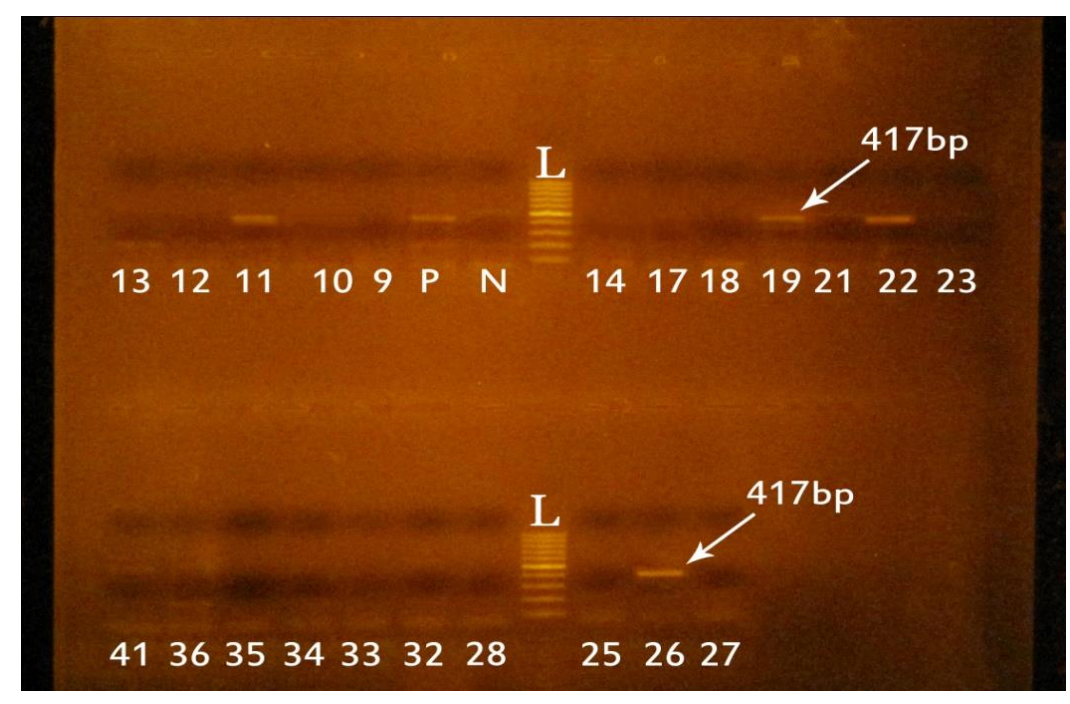

Fig. (3): Agarose gel electrophoresis showing specific PCR of Salmonella isolates using primer set for $q n r \mathrm{~S}$ gene (417 bp) - L= ladder\& lane $(1)=$ negative control\& lane $(2)=$ positive control and lanes $(11,19,22$ and 26 ) were positive for this gene. 


\section{REFERENCES}

- Ahmed, A.M., Ishida, Y., Shimamoto, T. (2009a): Molecular characterization of antimicrobial resistance in Salmonella isolated from animals in Japan. J. Appl. Microbiol. 106: 402-409.

- Ahmed, A.M., Younis, E.A., Ishida, Y., Shimamoto, T. (2009b): Genetic basis of multidrug resistance in Salmonella enterica serovars Enteritidis and Typhimurium isolated from diarrheic calves in Egypt. Acta Tropica 111 (2009) 144-149.

- Ammar,A., Alloui, N., Bennoune, O. and Kassah-Laouar, A. (2010): Survey of Salmonella serovars in broilers and laying breeding reproducers in East of Algeria. Journal Infection Dev Ctries. 4(2):103-106.

- Ang, J.Y. , Ezike, E. and Asmar, B.I. (2004): Antibacterial resistance. Indian Journal of Pediatrics. 71, 229-239.

- Angulo, F.J., Griffin, P.M., (2000) Changes in antimicrobial resistance in Salmonella enterica serovar typhimurium. Emerg. Infect. Dis. 6, 436-438.

- Bonyadian, M. , Ale Agha, S. and Motahari Fard, A. (2007): Isolation and identification of Salmonellae from chicken carcasses in processing plants in Yazd province, central Iran. Iranian Journal of Veterinary Research. 8 (3): 275-278.

- Boris H., Borka, S., Gordan, K., Fani, K. (2012). Antimicrobial resistance and serotyping of Salmonella enterica subsp. enterica isolated from poultry in Croatia. Vet. arhiv 82, 371-381, 2012. 
- Cattoir, V.; Poirel, L. and Nordmann, P. (2008): plasmid - mediated quinolone resistance pump QepA2 in an Escherichia coli isolated from France. Antimicrob Agents Chemother 52: 3801- 3804.

- Cardoso, M.O., Ribeiro, A.R., Santos, L.R., Pilotto, F., Moraes, H.S., Salle, C.P., Rocha, S.S., Nascimento, V.P. (2006). Antibiotic resistance of Salmonella Enteritidis isolated from broiler carcasses. Braz. J. Microbiol., 37: 368-371.

- Cavaco, L. M., H. Hasman, Xia S., and Aarestrup F. M. (2009).qnrD, a Novel Gene Conferring Transferable Quinolone Resistance in Salmonella enterica Serovar Kentucky and Bovismorbificans Strains of Human Origin. . Antimicrob. Agents Chemother, Feb. 2009, p. 603-608.

- CLSI (2005): Clinical and Laboratory Standards Institute performance standard for antimicrobial disc susceptibility tests, approved standards, 25 8th ed, M02- A8.

- Cruchaga,S., Echieta, A., Aladuena, A., Rena, J.G. and Usera, M.A. (2001): Antimicrobial resistance in Salmonella from human food and animals in Spain in 1998.J. Antimicrob. Chemother.; 47: 315 - 321.

- Dahal, N. (2007): Prevalence and Antimicrobial Resistance of Salmonella in Imported Chicken Carcasses in Bhutan, Master of Veterinary Public Health, Chiang Mai University and Freie Universität Berlin. P: 47.

- Edel, W. , Mijs, A. , Robinjs, K.G. , Vries, T.S. and Smak, J. (1991): The report of the working group on Salmonella Entertidis in poultry in 
the Netherlands. Surveillance and control in 1990/1991. Tijdschrift voor Diergeneeskunde, 116 (15/16): 806 - 811.

- $\quad \boldsymbol{E l}$-Morsi, M.E.M. (1998): Occurrence of food poisoning organisms in poultry products with special reference to Campylobacter . $\mathrm{PhD}$. Thesis (Meat Hygiene), Fac. Vet. Med., Zagazig Univ.

- El- Zeedy, S.A. , Eldeen, H.K. and Badr, G.M. (2007): Protein analysis for comparison between Salmonellae isolated from different poultry species. BS. Vet. Med. J., 17(2): 1- 9.

- Finegold, S. M. and Martin, E. T. (1982): Diagnostic microbiology. 6th Ed., The C.V. Mosby Company, St. Louis, Toronto, London.

- Gay, K., Robicsek, A., Strahilevitz, J., Park, C.H., Jacoby, G., Barrett, T.J., Medalla, F.,Chiller, T.M., Hooper, D.C., (2006). Plasmid-mediated quinolone resistance in non-Typhi serotypes of Salmonella enterica. Clin. Infect. Dis. 43, 297-304.

- Hata, M., M. Suzuki, M. Matsumoto, M. Takahashi, K. Sato, S. Ibe, and K. Sakae. (2005). Cloning of a novel e for quinolone resistance from a transferable plasmid in Shgenigella flexneri $2 \mathrm{~b}$. Antimicrob. Agents Chemother. 49: 801-803.

- Hopkins, K.L., Wootton, L., Day, M.R., Threlfall, E.J., (2007). Plasmid-mediated quinolone resistance determinant qnrS1 found in Salmonella enterica strains isolated in the UK. J. Antimicrob. Chemother. 59, 1071-1075.

- Ibrahim, H. S. (1995): Studies on colonization of intestine by Salmonella in poultry. Ph.D. Thesis, Fac. Vet. Med., Cairo Univ. 
- Islam, M. M. , Haider, M. G. , Chowdhury, E. H. , Kamruzzaman, M. and Hossain, M. M. (2006): Seroprevalence and pathological study of Salmonella infections in layer chickens and isolation and identification of causal agents. Bangladesh Journal of Veterinary Medicine. 4: 2, 79-85.

- ISO 6579 (2002) 4th ed: Microbiology -General guidance on methods for the detection of Salmonella, International organize for standardization, Geneve, Switzerland.

- Jacoby, G. A., K. E. Walsh, D. M. Mills, V. J. Walker, H. Oh, A. Robicsek, and D. C. Hooper. (2006). qnrB, another plasmid-mediated gene for quinolone resistance. Antimicrob. Agents Chemother. 50:1178-1182.

- Jacoby, G., V. Cattoir, D. Hooper, L. Martinez-Martinez, P. Nordmann, A. Pascual, L. Poirel, and M. Wang. (2008). qnr gene nomenclature. Antimicrob. Agents Chemother. 52:2297-2299.

- Jafari, R. A. , Ghorbanpour, M. and Jaideri, A. (2007): An investigation into Salmonella infection status in backyard chickens in Iran. International - Journal - of poultry Science.; 6(3): 227 - 229.

- Kauffmann, F. (1974): Serological diagnosis of Salmonella species. Kaufmann White Scheme, Copenhagen, Denmark.

- Kehrenberg, C., Friederichs, S., de Jong, A.,Michael, G.B., Schwarz, $S$. (2006). Identification of the plasmid-borne quinolone resistance gene qnrS in Salmonella enterica serovar Infantis. J. Antimicrob. Chemother. 58, 18-22. 
- Khan, M., Suryanarayan, P., Ahmed, M., Vaswani, R., Faheem, S. (2010). Antimicrobial susceptibility of Salmonella isolates from chicken meat samples in Dubai, United Arab Emirates. International Journal of Food, Nutrition and Public Health, Vol. 3, No. 2. pp: 149 159.

- Martinez-Martinez, L., A. Pascual, and G. A. Jacoby. (1998). Quinolone resistance from a transferable plasmid. Lancet 351: 797-799.

- Mohamed, L.N. , Samaha, H.A. , Draz, A.A. and Haggage, Y.N. (1999): Salmonellae among birds and human beings. Alex. J. Vet. Sci., 15 (1): 147 - 154.

- Munawwar, A., Priyanka, S., Mohammed, M., Reshma, B. and Sultan, M. (2010). Antimicrobial susceptibility of Salmonella isolates from chicken meat samples in Dubai, United Arab Emirates. International Journal of Food, Nutrition and Public Health, Vol. 3, No. 2, 2010.

- Osman, M.M. (1992): Studies on bacterial causes of early poultry mortality in Sharkia Governorate. M.V.Sc. Thesis (Bacteriology) Fac. Vet. Med. Zagazig Univ.

- Rehan, H.M.A. (2004): Application of PCR identification of Salmonella in chickens. M.V.Sc., Thesis, Fac. Vet. Med., Mansoura Univ. 
- Robicsek,A., Jacoby, G.A., Hooper, D.C., (2006a). Theworldwide emergence of plasmid mediated quinolone resistance. Lancet Infect. Dis. 6, 629-640.

- Robicsek,A., Strahilevitz, J., Sahm, D.F., Jacoby, G.A., Hooper, D.C., (2006b). qnr prevalence in ceftazidime-resistant Enterobacteriaceae isolates from the United States. Antimicrob. Agents Chemother. 50, 2872-2874.

- Ruiz, J., 2003. Mechanisms of resistance to quinolones: target alterations, decreased accumulation and DNA gyrase protection. J. Antimicrob. Chemother. 51,1109-1117.

- Schluter, H. , Beyer, W. , Hagelschuer, I. , Geue, I. and Hagelschuer, P. (1994): Epidemiological studies on Salmonella infections in poultry flocks. Tierarztliche Umschau, 49(7): $400-410$.

- Snow, L.C., Davies, R.H., Christiansen, K.H., Carrique-Mas, J.J., Cook, A.J., Evans, S.J. 2011. Survey of Salmonella prevalence on commercial turkey breeding and fattening farms in the UK in 2006 to 2007. Vet Rec. 2011 Nov 5; 169(19):493.

- Toh, S.L. , Teo, T.P. and Tay, Y.H. (1996): Salmonella serotypes isolated in Central Veterinary Laboratory between 1990 and 1994. Singapore. J. Of primary Industries, 24: 67-80.

- Verma, J.C. and Gupta, B.R. (1995): Occurrence of Salmonella serotypes in animals in India. Ind. J. Comp. Microbiol. Immmnol. Infec. Dis., $16(3-4)$ : $104-108$. 
- Wang, M. H., X. Xu, S. Wu, D. Zhu, and M. G. Wang. 2008. A new plasmid mediated gene for quinolone resistance, qnrC, abstr. O207. Abstr. 18th Eur. Congr. Clin. Microbiol. Infect. Dis., Barcelona, Spain.

- Xiang Chen, Weijuan Pan, Weiqiu Zhang, Zhiming Pan, Song Gao and Xinan Jiao(2011). Quinolone resistance in Escherichia coli and Salmonella spp. isolates from diseased chickens during 1993-2008 in China African Journal of Microbiology Research Vol. 5(19), pp. 3078-3083, 23 September, 2011.

- Zdragas, A., Mazaraki, K., Vafeas, G., Giantzi, V., Papadopoulos, T., Ekateriniadou, L. 2012. Prevalence, seasonal occurrence and antimicrobial resistance of Salmonella in poultry retail products in Greece. Letters in Applied Microbiology. 55(4):308-313, October 2012. 